\title{
Selection of Yeasts Antagonists as Biocontrol Agent of Mango Fruit Rot caused by Botryodiplodia theobromae
}

\author{
DWI SUGIPRIHATINI ${ }^{1}$, SURYO WIYONO ${ }^{2 *}$, \\ AND WIDODO ${ }^{2}$ \\ ${ }^{1}$ Balai Besar Uji Standar Karantina Pertanian, Jalan Pemuda No 64 Kav16-17, \\ Rawamangun, Jakarta 13220, Indonesia; \\ ${ }^{2}$ Department of Plant Protection, Faculty of Agriculture, Institut Pertanian Bogor, \\ Darmaga Campus, Bogor 16680, Indonesia
}

\begin{abstract}
Fruit rot caused by Botryodiplodia theobromae is one of the most important post harvest disease of mango in Indonesia. Study on biological control on the disease is required to develop environmentally-sound control technology. The research objectives were to study the potency of yeasts in controlling post harvest mango disease i.e. fruit rot caused by $B$. theobromae and mechanism involve in the biocontrol. Total yeast isolates used for screening were twenty one, four from collection of Plant Clinic of Institut Pertanian Bogor, and twenty one isolated from healthy mango skin. All of yeast isolates were characterized and identified using BIOLOG. Bioassay on antagonistic activity of yeasts against fruit rot, in-vitro dual culture test and chitinolytic activity were carried out. Cryptococcus albidus var. aerius WSW1, Pichia guilliermondii K1, and Debaryomyces hansenii $\mathrm{K} 12$ were the three most effective antagonistic yeasts against $B$. theobromae with effectiveness of $70.83,45.83,37.50 \%$ respectively. In vitro bio-assay showed that $C$. albidus var. aerius WSW1, C. albidus WSW2, C. albidus K6, C. terreus YSW1, Candida edax OSW1, Candida edax K13, and Cryptococcus luteolus K2 had high antibiosis activity. Biocontrol activity of tested yeasts against fruit rot of mango did not correlate to its antibiosis and chitinolytic activity.
\end{abstract}

Key words: biocontrol, Botryodiplodia theobromae, Cryptococcus albidus, mango, yeast

Busuk buah yang disebabkan Botryodiplodia theobromae merupakan salah satu penyakit pasca panen mangga terpenting di Indonesia. Penelitian tentang pengendalian hayati penyakit tersebut diperlukan untuk mengembangkan teknologi pengendalian yang ramah lingkungan. Penelitian ini bertujuan mengkaji potensi khamir antagonis dalam pengendalian busuk buah mangga yang disebabkan $B$. theobromae dan beberapa mekanisme yang terlibat. Isolat khamir diperoleh dari koleksi Klinik Tanaman Institut Pertanian Bogor (IPB), yang diisolasi oleh salah seorang penulis dan diisolasi dari buah mangga sehat. Isolasi khamir dilakukan dengan pencucian kulit buah yang dilanjutkan dengan penanaman pada media PDA pH 5.5. Jumlah isolat khamir yang diseleksi semuanya ada 21, 4 dari koleksi Klinik Tanaman IPB dan 17 dari hasil isolasi penulis. Semua isolat khamir identifikasi dengan BIOLOG. Semua isolat khamir dikaji kemampuan antagonisnya terhadap busuk buah, uji koloni ganda in-vitro dan uji aktivitas kitinase. Cryptococcus albidus var. aerius WSW1, Pichia guilliermondii $\mathrm{K} 1$, dan Debaryomyces hansenii K12 adalah tiga isolat khamir antagonis paling efektif terhadap B. theobromae dengan tingkat penekanan secara berturut-turut $70.83,45.83$, dan 37.50\%. Uji koloni ganda in-vitro menunjukkan bahwa C. albidus var. aerius WSW1, C. albidus WSW2, C. albidus K6, C. terreus YSW1, Candida edax OSW1, Candida edax K13, dan C. luteolus K2 mempunyai aktivitas antibiosis yang tinggi. Keefektifan pengendalian hayati khamir yang diuji terhadap busuk buah mangga tidak berkorelasi dengan aktivitas antibiosis dan kitinase khamir tersebut.

Kata kunci: Cryptococcus albidus, Botryodiplodia theobromae, khamir, mangga, pengendalian hayati

Mango is one of important tropical fruit commodity for many tropical countries for domestic trade and -also export. One major post harvest disease in Indonesia is fruit rot caused by Botryodiplodia theobromae, causing serious damage in storage and shipping. Infection rate of disease on mango fruit $c v$. Arumanis was average 54\% (Yulianingsih et al. 1990). There are no effective control measures against this disease. Existing control measures is the application of fungicide after harvest. The fungicide use has low consumer's acceptance due to environment and health issues.

Biological control using yeasts is a promising alternative to control post harvest diseases of fruits and

*Corresponding author, Phone/Fax: +62-251-8423048, E-mail: suryow@hotmail.com vegetables. The advantages using yeast for biocontrol agent i.e. it grows fast, dry tolerance; do not produce mycotoxin and allergenic spores (Droby and Chalutz 1994). Previous research showed that yeasts can be applied to delay fruit ripening process and disease control as well (Janisiewicz and Korsten 2002). Delay of fruit ripening by yeast is through inhibition of ethylene production (Droby et al. 1997). Some research showed that some yeasts are effective biocontrol agent of post harvest diseases (Fan and Tian 2001; Janisiewicz and Korsten 2002) The use of Pichia guilliermondii was effective to control anthracnose of chili caused by Colletotrichum gloeosporioides in storage (Chanchaichaovivat et al. 2007). In addition, Candida membranifaciens was also effective biocontrol agents against anthracnose, a post harvest disease of mango (Kefialew and Ayalew 2008). 
Information on the use of yeast to control fruit rot of mango is not available. The objectives of this research were to investigate the potency of yeasts as biocontrol agent of fruit rot of mango caused by $B$. theobromae and to examine mechanism involved in the biocontrol.

\section{MATERIALS AND METHODS}

Yeast Used in This Study. Twenty one yeasts isolates were used in this study. Four yeasts isolates (WSW1, WSW2, OSW1, and YSW1) were obtained from Plant Clinic of Institut Pertanian Bogor. Seventeen other yeast isolates were obtained from healthy mango fruit originated from Cirebon, West Java.

Yeast isolation from fresh fruit of mango was done by skin washing than serial dilution technique up to 10000 and continued by plating onto potato dextrose agar (PDA) pH 5.5. The isolated yeasts then purified and identified physiologically up to species level by using BIOLOG TM (Micro Log TM System, release 4.2). The pathogen $B$. theobromae was isolated from infected mango fruit by tissue plating technique and cultivated on PDA pH 5.5 and identified morphologically by based on Watanabe (2002).

Biocontrol Assay by in-vivo Test. Selection of yeast isolates for biocontrol effectiveness was conducted according to modified technique of Kefialew and Ayalew (2008). All of yeast were cultured on potato dextrose broth (PDB) $\mathrm{pH} 5.5$ and shaken at $100 \mathrm{rpm}$ for 3 days. Mango $\mathrm{cv}$. "Gedong Gincu" were obtained from farmer's field in Cirebon, West Java and kept under cool box and stored in refrigerator before handled. Mango fruits were disinfected by sodium hypochloride $1 \%$ for $1 \mathrm{~min}$ and rinsing by sterilized water and air dried. Thereafter mango fruit was dipped by yeast suspension at density of $10^{6}$ cells $\mathrm{mL}^{-1}$ for $1 \mathrm{~min}$, then air dried. Skin fruit was taken up by knife up to size of $8 \mathrm{~cm} \times 3 \mathrm{~cm}$, put and placed into moistened $30 \mathrm{~cm} \times 20 \mathrm{~cm} \times 4 \mathrm{~cm}$ plastic pans. Preliminary research shows that disease severity produced by artificial inoculation of $B$. theobromae on mango fruit skin highly correlated to whole fruit inoculation. Then conidia of 7-day old of $B$. theobromae grown on PDA at the rate of $10^{6} \mathrm{~mL}^{-1}$ as $50 \mu \mathrm{L}$ was pippeted on the yeast-treated mango skin, then mangos skin was incubated under dark for $24 \mathrm{~h}$ then incubated for 5 days. Disease severity was assessed by necrotic percentage of skin (Kefialew and Ayalew 2008). Biocontrol efficacy (BE) of yeasts was calculated using formulae of Chanchaichaovivat et al. (2007) as follow:

$$
\mathrm{BE}=(\mathrm{dc}-\mathrm{dt}) / \mathrm{dc} \times 100 \% ;
$$

where BE, biocontrol efficacy (\%); dc, disease severity of control; dt, disease severity of treatment.
Fruits dipping with sterilized water and fungicide with active ingredients thiram (Tiflo $80 \mathrm{WP}$ ) at the rate of $0.1 \%(\mathrm{w} / \mathrm{v})$ for $1 \mathrm{~min}$ were applied for negative and positive control respectively.

The experiment was carried out using randomized complete designed with 4 replications.

Dual Culture Assay. Dual culture assay was performed to determine if biocontrol mechanism is antibiosis (Wisniewski et al. 2007). All of yeasts isolates were tested against fruit rot fungi $B$. theobromae. Yeast was streaked forming line in the middle of 9-mm petridish containing PDA. Agar plug $\varnothing 3 \mathrm{~mm}$-7- day old $B$. theobromae was seeded on the right and left of yeast streak, therefore line connecting two fungal colony centers was perpendicular to the yeast streak. Inhibition zone was assessed after 3 days of incubation and expressed in $\mathrm{cm}$. The size of inhibition zone indicated antibiosis of yeasts against tested fungus (Spadaro 2002; Indriatmi 2008). All of treatments was arranged in randomized complete design and three times replicated.

Chitinolytic Activity. All yeast isolates were grown on chitin agar, containing $0.5 \%$ colloidal chitin for 3 days (Shanmugaiah et al. 2008). Chitinolytic activity was indicated by formation of clear zone surrounding yeast colony.

\section{RESULTS}

Identification using BIOLOG resulted that there was variability of yeast originated from fructoplane of mango and Plant Clinic of IPB collection (from shallot's leaves). Four yeast isolates from plant clinic collection were identified as three species i.e. Cryptococcus albidus var. aerius WSW1, C. albidus var. aerius WSW2, Candida edax OSW 1. Only one isolate of plant clinic was a different species as from mango fructoplane i.e. C. terreus YSW1. Moreover, seventeen yeast isolates from mango consisted of 11 species i.e. Candida edax, Candida mexicana, Candida terestre, Bulleromyces albus, C. albidus var. aerius, Cryptococcus amylololentus, Cryptococcus luteolus, Debaryomyces hansenii, Pichia guilliermondii, Rhodotorula aurentica, and R. glutinis.

Bioassay on biocontrol effectiveness showed that some yeasts isolates had ability to suppress fruit rot caused by $B$. theobromae (Table 2). Three isolates had disease biocontrol effectiveness rate over 35\% which were $C$. albidus var. aerius WSW1, $P$. guilliermondii $\mathrm{K} 1, D$. hansenii $\mathrm{K} 12$ with biocontrol effectiveness as $70.83,45.83$ and $37.5 \%$, respectively. Such effectiveness rate was comparable, even higher than standard fungicide Tiflo $80 \mathrm{WP}$ with active ingredient thiram that had 35\% (Table 2, Fig 1). Other important 
Table 1 Identification of yeasts isolates using BIOLOG TM

\begin{tabular}{|c|c|c|c|}
\hline Isolates & Origins & Identified species & Probability (\%) \\
\hline WSW1 & Plant Clinic (Shallot, Brebes) & Cryptococcus albidus var. aerius & 100 \\
\hline WSW2 & Plant Clinic (Shallot, Brebes) & Cryptococcus albidus var. aerius & 100 \\
\hline OSW1 & Plant Clinic (Shallot, Brebes) & Candida edax & 100 \\
\hline YSW1 & Plant Clinic (Shallot, Brebes) & Cryptococcus terreus & 84 \\
\hline K1 & Mango, Cirebon & Pichia guilliermondii & 94 \\
\hline $\mathrm{K} 2$ & Mango, Cirebon & Cryptococcus luteolus & 91 \\
\hline K3 & Mango, Cirebon & Debaryomyces hansenii & 99 \\
\hline K4 & Mango, Cirebon & Candida terestre & 54.7 \\
\hline K5 & Mango, Cirebon & Candida edax & 94 \\
\hline K6 & Mango, Cirebon & Cryptococcus albidus var. aerius & 99 \\
\hline K7 & Mango, Cirebon & Bulleromyces albus & 99 \\
\hline K8 & Mango, Cirebon & Rhodotorula glutinis & 100 \\
\hline K9 & Mango, Cirebon & Pichia guilliermondii & 99 \\
\hline K10 & Mango, Cirebon & Cryptococcus albidus var. aerius & 99 \\
\hline K11 & Mango, Cirebon & Rhodotorula aurantica & 99 \\
\hline $\mathrm{K} 12$ & Mango, Cirebon & Debaryomyces hansenii & 98 \\
\hline K13 & Mango, Cirebon & Candida edax & 99 \\
\hline K14 & Mango, Cirebon & Pichia guilliermondii & 99 \\
\hline K15 & Mango, Cirebon & Candida mexicana & 99 \\
\hline K16 & Mango, Cirebon & Cryptococcus amylololentus & 84 \\
\hline K17 & Mango, Cirebon & Debaromyces hansenii & 99 \\
\hline
\end{tabular}

Table 2 Biocontrol effectiveness of yeasts against fruit rots of mango

\begin{tabular}{llcc}
\hline Isolate Codes & Yeast species & Disease severity (\%) & Biocontrol efficacy (\%) \\
\hline WSW1 & Cryptococcus albidus var. aerius & $29.17 \pm 5.13 \mathrm{~g}$ & 70.83 \\
WSW2 & Cryptococcus albidus var. aerius & $87.50 \pm 4.54 \mathrm{~b}$ & 12.50 \\
OSW1 & Candida edax & $91.67 \pm 4.37 \mathrm{~b}$ & 8.33 \\
YSW1 & Cryptococcus terreus & $75.00 \pm 5.81 \mathrm{~cd}$ & 25.00 \\
K1 & Pichia guilliermondii & $54.17 \pm 4.69 \mathrm{f}$ & 45.83 \\
K2 & Cryptococcus luteolus & $91.67 \pm 6.53 \mathrm{~b}$ & 8.33 \\
K3 & Debaryomyces hansenii & $91.67 \pm 6.53 \mathrm{~b}$ & 8.33 \\
K4 & Candida terestre & $95.83 \pm 4.46 \mathrm{ab}$ & 4.17 \\
K5 & Candida edax & $100.00 \pm 0.00 \mathrm{a}$ & 0.00 \\
K6 & Cryptococcus albidus var. aerius & $95.83 \pm 4.46 \mathrm{ab}$ & 4.17 \\
K7 & Bulleromyces albus & $95.83 \pm 4.46 \mathrm{ab}$ & 4.17 \\
K8 & Rhodotorula glutinis & $70.83 \pm 6.72 \mathrm{~d}$ & 29.17 \\
K9 & Pichia guilliermondii & $75.00 \pm 4.85 \mathrm{~cd}$ & 25.00 \\
K10 & Cryptococcus albidus var. aerius & $79.17 \pm 4.48 \mathrm{c}$ & 20.83 \\
K11 & Rhodotorula aurentica & $75.00 \pm 4.35 \mathrm{~cd}$ & 25.00 \\
K12 & Debaryomyces hansenii & $62.51 \pm 6.53 \mathrm{e}$ & 37.50 \\
K13 & Candida edax & $70.83 \pm 5.72 \mathrm{~d}$ & 29.17 \\
K14 & Pichia guillermondii & $91.67 \pm 6.53 \mathrm{~b}$ & 6.33 \\
K15 & Candida mexicana & $87.50 \pm 7.44 \mathrm{~b}$ & 12.5 \\
K16 & Cryptococcus amylololentus & $70.83 \pm 6.53 \mathrm{~d}$ & 29.17 \\
K17 & Debaryomyces hansenii & $100.00 \pm 0.00 \mathrm{a}$ & 0.00 \\
& Untreated (water) & $100.00 \pm 0.00 \mathrm{a}$ & -
\end{tabular}

Note: numbers followed by same symbols are not significantly different according DMRT test at $\alpha=0.05$

finding was even though some isolates belong to the same species they had very different antagonistic activities. For instance, species C. albidus var. aerius only isolates WSW1 had high antagonistic activity (70.83\%), other isolates i.e. WSW2, K6, and $\mathrm{K} 10$ which had no antagonistic activity.

The yeasts had variability in antibiosis indicating by the size of inhibition zone (Table 3 ). Some yeasts had strong antibiosis in-vitro against $B$. theobromae such as $C$. albidus var. aerius. In-vitro-dual culture test showed that $C$. albidus var. aerius WSW1, C. albidus
WSW2, Ca. edax OSW1, C. terreus YSW1, C. luteolus $\mathrm{K} 2$, Ca. edax K13, C. albidus K6 had high antibiosis activity. Furthermore, other yeast isolates had lower antibiosis activity. Interestingly, there was no correlation between antibiosis activity in vitro and biocontrol efficacy. Among yeasts having high efficacy rate against fruit rot disease, only $C$. albidus var. aerius WSW1 was effective yeasts and had high antibiosis activity. Other effective yeasts $P$. guilliermondii $\mathrm{K} 1$ and $D$. hansenii $\mathrm{K} 7$ had low antibiosis activity (Table 3 ). 

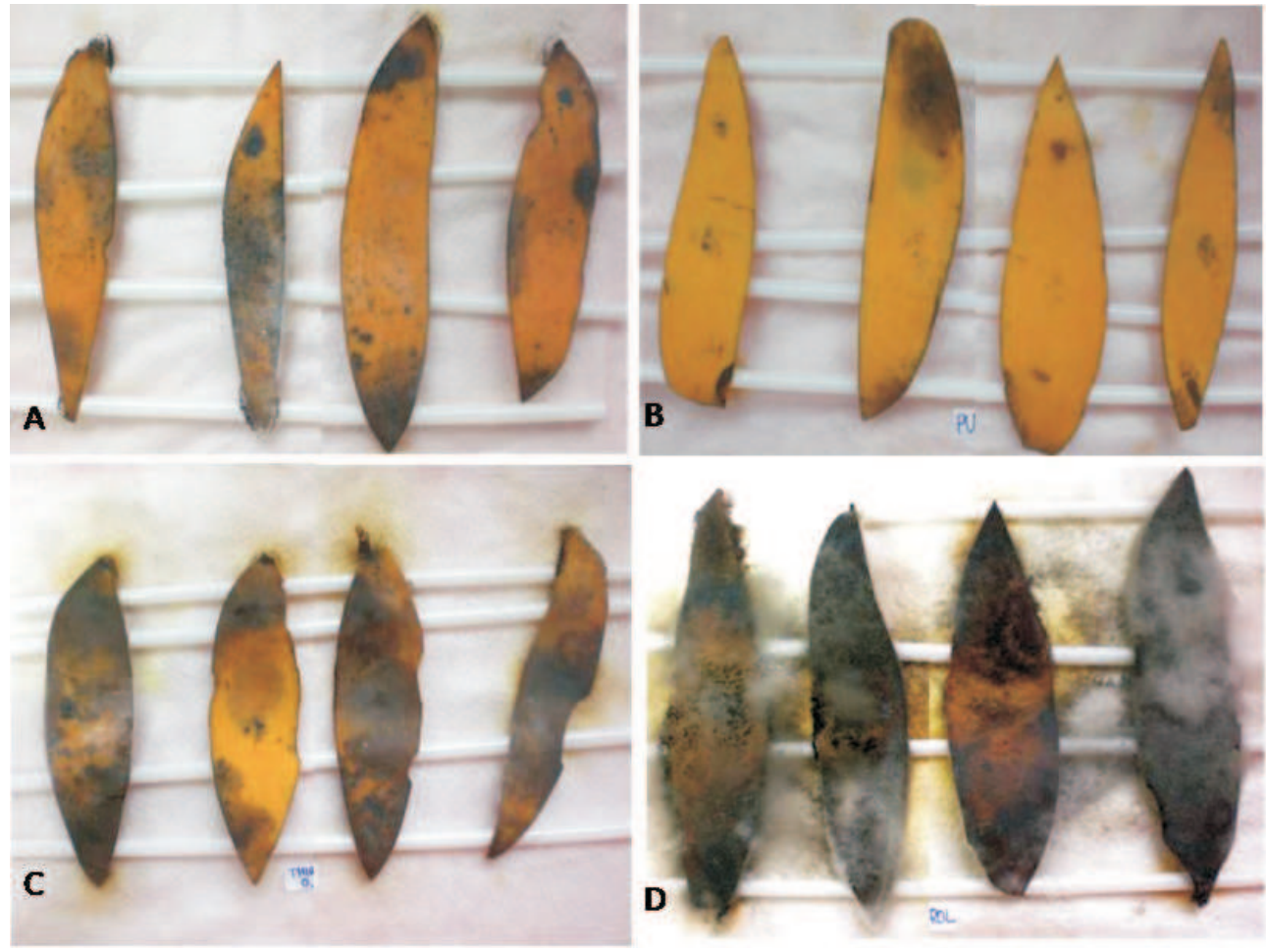

Fig 1 Effectiveness of antagonistic yeasts against fruit rot disease of mango caused by Botryodiplodia theobromae in bioassay using mango skin. Note: A. Pichia guilliermondii K1, B. Cryptococcus albidus var. aerius WSW1, C. Fungicide (thiram), D. Untreated

Table 3 Antibiosis of yeasts against Botryodiplodia theobromae and their chitinolytic activity

\begin{tabular}{llcc}
\hline \multicolumn{1}{c}{ Code } & \multicolumn{1}{c}{ Species } & Inhibition zone $(\mathrm{cm})$ & Chitinolytic activity \\
\hline WSW1 & Cryptococcus albidus var. aerius & $2.10 \pm 0.23 \mathrm{a}$ & - \\
WSW2 & Cryptococcus albidus var. aerius & $1.97 \pm 0.16 \mathrm{ab}$ & - \\
OSW1 & Candida edax & $1.80 \pm 0.12 \mathrm{bc}$ & - \\
YSW1 & Cryptococcus terreus & $1.83 \pm 0.12 \mathrm{bc}$ & - \\
K1 & Pichia guilliermondii & $0.37 \pm 0.11 \mathrm{ij}$ & - \\
K2 & Cryptococcus luteolus & $1.67 \pm 0.12 \mathrm{c}$ & - \\
K3 & Debaryomyces hansenii & $0.50 \pm 0.21 \mathrm{i}$ & - \\
K4 & Candida terestre & $1.20 \pm 0.26 \mathrm{de}$ & - \\
K5 & Candida edax & $0.70 \pm 0.33 \mathrm{j}$ & - \\
K6 & Cryptococcus albidus var. aerius & $1.47 \pm 0.18 \mathrm{~d}$ & - \\
K7 & Bulleromyces albus & $0.50 \pm 0.18 \mathrm{i}$ & + \\
K8 & Rhodotorula glutinis & $0.47 \pm 0.19 \mathrm{i}$ & - \\
K9 & Pichia guilliermondi & $1.00 \pm 0.10 \mathrm{fg}$ & - \\
K10 & Cryptococcus albidus var. aerius & $1.17 \pm 0.15 \mathrm{ef}$ & - \\
K11 & Rhodotorula aurentica & $0.50 \pm 0.20 \mathrm{i}$ & - \\
K12 & Debaryomyces hansenii & $0.40 \pm 0.22 \mathrm{i}$ & - \\
K13 & Candida edax & $1.43 \pm 0.21 \mathrm{~d}$ & - \\
K14 & Pichia guilliermondii & $1.03 \pm 0.89 \mathrm{fg}$ & - \\
K15 & Candida mexicana & $1.07 \pm 0.25 \mathrm{f}$ & - \\
K16 & Cryptococcus amylololentus & $0.97 \pm 0.14 \mathrm{fg}$ & - \\
K17 & Debaryomyces hansenii & $0.57 \pm 0.14 \mathrm{i}$ & - \\
\hline
\end{tabular}

Note: + forming clear zone, numbers followed by same symbols are not significantly different according DMRT test at $\alpha=0.05$

Among yeasts tested, only Bulleromyces albus K7 and $P$. guilliermondii $\mathrm{K} 14$ had chitinolityic activity (Table 3). Those two yeasts had low biocontrol efectiveness.

\section{DISCUSSION}

Fructoplane and phylloplane are rich source of microbes, in which yeast is dominant group followed by bacteria and filamentous fungi (Elmer and Reglinski 2002). The number of isolated yeasts from fructoplane of mango in this study was 11 species i.e. Ca. edax, Ca. mexicana, Ca. terestre, B. albus, C. albidus var. aerius, C. amylololentus, C. luteolus, D. hansenii, P. guilliermondii, $R$. aurentica, and $R$. glutinis. Some of isolated yeasts were potential as biocontrol agent i.e. C. albidus var. aerius WSW1, $P$. 
guilliermondii $\mathrm{K} 1$, and $D$. hansenii $\mathrm{K} 12$ indicated by having biocontrol efficacy rate over $35 \%$. Yeasts belong to the genus Pichia, such as $P$. anomala, $P$. membranifaciens, and $P$. guilliermondii have been reported as effective biocontrol agents against various post harvest diseases (Elmer and Reglinski 2001; Fan and Shiping 2002; Chancaichivat et al. 2008). Moreover Debaryomyces sp. is also reported by lesser extent as biocontrol agent of post harvest diseases (McLaughlin et al. 1990).

The most effective yeast antagonist obtained in the study is C. albidus var. aerius WSW1. Even though there are not many report on biocontrol using Cryptococcus, some species of Cryptococcus were reported as biocontrol agent, e.g., C. infirmo-miniatus and $C$. laurentii against pear rot disease (Benbow and Sugar 1999), C. laurentii against blue mold of peach (Zhang et al. 2007), and C. albidus against blue and grey mold of apple (Fan and Tian 2010). It is interesting that one yeast isolate, $C$. albidus var. aerius WSW1 was very effective against fruit rot of mango $(70.83 \%$ of biocontrol efectiveness) (Fig 1, Table 2), it was even higher than fungicide Tiflo 80 WP with active ingredients thiram that provide $35 \%$. As comparison, research of Kefialew and Ayalew (2008) showed that the use Candida membranifaciens as biocontrol yeasts on mango anthrachnose provided efficacy rate of $82 \%, C a$. membranifaciens on grey mold $61 \%-81 \%$ (Gholamnejad et al. 2010). This effectiveness of C. albidus var. aerius WSW1 used in the study was very high and promising, because it was achieved under extreme disease conducive environment, in which diseases pressure is very high (conidia density $\left.10^{6} \mathrm{~mL}^{-1}\right)$, and incubated in moistened $(100 \%$ relative humidity) and darkened environment. In standard storage condition, the effectiveness is expected to be higher. Further test on combination of the yeast and real storage condition is necessary Other technique to increase efficacy are combining with other species, and or application and formulation optimization (Janisiewicz 1996).

Based on data obtained in this experiment, even isolates WSW1, WSW2, K6, and K10 referred to species $C$. albidus var. aerius, they were very different in their antagonistic activity, only WSW1 had effective biocontrol activity. This shows that biocontrol effectiveness of tested yeasts is isolate-base and not species-base. Even though yeast isolates belong to same species, may have different antagonistic activity, therefore biocontrol activity test is necessary for each isolates.

Mechanism of biocontrol is necessary to be recognized, therefore a biocontrol agent can further developed and optimized. There are various mechanism involve in biocontrol using yeasts competition, antibiosis, lysis and resistance induction (Janisiewicz and Korsten 2001; De Ingeniis 2004; Wisniewski et al. 2007). Weak correlation of antibiosis activity in-vitro and biocontrol efectiveness such as depicted in Table 2 and Table 3 , show that antibiosis is not main mechanism underlying biocontrol of yeasts. In this research, antibiosis is valid only for biocontrol mechanism of C. albidus var. aerius.

Even though other previous researcher reported that chitinolytic and other lytic enzyme activity involve in mechanism of biocontrol using yeast (Spadaro 2002; Masih and Paul 2002), this study showed no relation between chitinolytic activity and biocontrol effectiveness of yeasts. Nutrients competition and induced resistance which involve in biological control control using yeast (Janisiewicz and Korsten 2001; El-Tarabily 2004; Yao and Tian 2005) were not investigated in this study. Further study to examine the role of induced resistance and competition of the three antagonistic yeasts is required.

The study yielded three potential antagonistic yeasts effective against fruit rot of mango. Some of mechanism of antagonism has also been investigated. Thus one of important initial step in developing biocontrol agent has been carried out. Further study is needed to develop them as biocontrol agents: other mechanism involved, efficacy with real storage condition, environment and nutritional affecting factors, mass production and formulation technology.

\section{ACKNOWLEDGEMENT}

The first author would like to Indonesian Plant Quarantine Agency for providing opportunity and post graduate scholarship in Institut Pertanian Bogor, for financial and laboratory support for conducting the research.

\section{REFERENCES}

Brzezinska MS, Donderski W. 2001. Occurrence and activity of the chitinolytic bacteria of Aeromonas genus. Pol J Environ Stud. 10(1):27-31.

Benbow JM, Sugar D. 1999. Fruit surface colonization and biological control of postharvest diseases of pear by preharvest yeast applications. Plant Dis. 83 (9):839-844.

Chanchaichaovivat A, Ruenwongsa P, Panijpan B. 2007. Screening and identification of yeast strains from fruits and vegetables: potential for biological control of postharvest chili anthracnose (Colletotrichum capsici). Biol Control. 42(1):326-335. doi:10.1016/j.biocontrol.2007. 05.016 .

Chanchaichaovivat A, Panijpan B, Ruenwongsa P. 2008. Putative modes of action of Pichia guilliermondii strain R13 in controlling chili anthracnose after harvest. Biol Control. 47(2):207-215. doi: 10.1016/j.biocontrol.2008.07.018.

De Ingeniis J, Raffaelli N, Maurizio C, Mannazzu I. 2009. Pichia anomala DBVPG 3003 secretes a ubiquitin-like protein that has antimicrobial 
activity. Appl Environ Microbiol. 75(4):1129-1134. doi:10.1128/ AEM01837-08.

Droby S, Vinokur V, Weiss B, Cohen L, Daus A, Goldschmidt EE, Porat R. 2002. Induction of resistance to Penicillium digitatum in grapefruit by the yeast biocontrol agent Candida oleophila. Phytopathology. 92(4):393-399.

El-Ghaouth A, Smilanick JL, Brown GE, Ippolito A, Wisniewski M, Wilson CL. 2000. Application of Candida saitoana and glycolchitosan for the control of postharvest diseases of apple and citrus fruit under semi-commercial conditions. Plant Dis. 84(3):243-248.

Elmer PAG, Reglinski T. 2006. Biosuppresion of Botrytis cinerea in grapes. Plant Pathol. 55(2):155-177. doi: 10.1111/j.1365-3059.2006.01348.x.

El-Tarabily, KA. 2004. Suppression of Rhizoctonia solani diseases of sugar beet by antagonistic and plant growth-promoting yeasts. J Appl Microbiol. 96(1):6975. doi: 10.1046/j.1365-2672.2003.02043.x.

Fan Q, Tian SP. 2001. Postharvest biological control of grey mold and blue mold on apple by Cryptococcus albidus (Saito) Skinner. Postharvest Biol Technol. 21(3):341-350. doi:10.1016/S0925-5214(00)00182-4

Gholamnejad J, Etebarian HR, Sahebani N. 2010. Biological control of apple blue mold with Candida membranifaciens and Rhodotorula mucilaginosa. Afr J Food Sci 4(1):001-007.

Janisiewicz WJ. 1996. Ecological diversity, niche overlap and coexistence of antagonist used in developing mixtures for biocontrol of postharvest diseases of apples. Phytopathology 86(5):473-479.

Janisiewicz WJ, Korsten L. 2002. Biological control of postharvest diseases of fruits. Annu Rev Phytopathol. 40:411-41. doi:10.1146/ annurev.phyto.40.120401.130158.

Kefialew Y, Ayalew A. 2008 . Postharvest biological control of anthracnose (Colletotrichum gloeosporioides) on mango (Mangifera indica) . Postharvest Biol Technol. 50(1):8-11. doi:10.1016/j.postharvbio. 2008.03.007

Khalimi, K. 2010. Pemanfaatan ragi dalam pengendalian penyakit tumbuhan yang ramah lingkungan [The use of yeast (Saccharomyces sp.) in environmental-friendly plant diseases control]. J Bumi Lestari. 10(2): 215-221.

Masih EI, Paul B. 2002. Secretion of ß-1,3 glucanases by the yeast Pichia membrafaciens and Its possible role in biocontrol of Botrytis cinerea causing grey mold disease of the grapevine. Curr Microbiol. 44(6): 391-395. doi: 10.1007/s00284-001-0011-y.
McLaughlin RJ, Wilson CL, Chalutz E, Kurtzman CP, Fett WF, Osman SF. 1990. Characterization and reclassification of yeast used for biological control of postharvest diseases of fruits and vegetables. Appl Environ Microbiol. 56(11):3583-3586.

Qing F, Shiping T. 2000. Postharvest biological control of Rhizopus rot of nectarine fruits by Pichia membranefaciens. Plant Dis. 84(11):12121216. doi: 10.1094/PDIS.2000.84.11.1212.

Saligkarias D, Gravanis FT, Epton HAS. 2002. Biological control of Botrytis cinerea on tomato plants by the use of epiphytic yeasts Candida guilliermondii strains 101 and US 7 and Candida oleophila strain I-182: II. a study on mode of action. Biol Control. 25(2):115119. doi:10.1016/S1049-9644(02)00051-8.

Shanmugaiah N, Mathivanan N, Balasubramanian A, Manoharan PT. 2008. Optimization of cultural conditions for production of chitinase by Bacillus laterosporous MML2270 isolated from rice rhizosphere soil. Afr J Biotech. 7(15): 2562-2568, doi:10.1016/S1473-3099(08) 70229-9.

Spadaro D. 2002. Biological control of postharvest diseases of pome fruit using yeast antagonists. [dissertation]. Torino (IT): Torino University.

Watanabe T. 2002. Pictorial Atlas of Soil and Seed Fungi: Morphologies of Cultured Fungi and Key to Species. 2nd ed. (Boca Raton US): CRC Pr.

Wisniewski M, Wilson C, Droby S, Chalutz E, El Ghaouth A, Stevens C. 2007. Postharvest Biocontrol: New Concepts and Applications. In: Vincent C, Goettel MS, Lazarovits G, editors. Biological Control: a Global Perspective. Wallingford (UK):CAB International. p 262-273.

Yao HJ, Tian SP. 2005. Effects of a biocontrol agent and methyl jasmonate onpostharvest diseases of peach fruit and the possible mechanisms involved. J App Microbiol. 98:941950. doi:10.1111/j.13652672.2004.02531.x

Yulianingsih, Broto W, Sabari SD. 1990. Inventarisasi penyakit pasca panen mangga cv. Arumanis, Gedong dan Cengkir [Inventory of post harvest disease of mango cv. Arumanis, Gedong dan Cengkir]. Hortikultura 29(1): 46-49.

Zhang H, Zheng X, Yu T. 2007. Biological control of postharvest diseases of peach with Cryptococcus laurentii. Food Control 18: 287-291. doi:10.1016/j.foodcont.2005.10.007. 